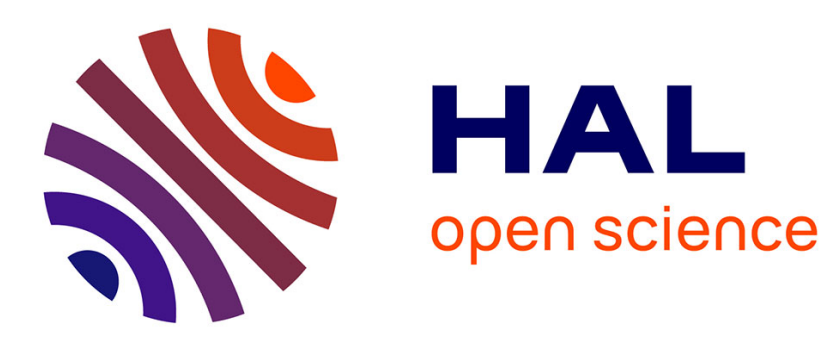

\title{
The development and commercialization of solar pv technology in the oil industry
}

\author{
Jonatan Pinkse, Daniel van den Buuse
}

\section{To cite this version:}

Jonatan Pinkse, Daniel van den Buuse. The development and commercialization of solar pv technology in the oil industry. Energy Policy, 2012, 40, p. 11-20. 10.1016/j.enpol.2010.09.029 . hal-00763647

\section{HAL Id: hal-00763647 \\ http://hal.grenoble-em.com/hal-00763647}

Submitted on 11 Dec 2012

HAL is a multi-disciplinary open access archive for the deposit and dissemination of scientific research documents, whether they are published or not. The documents may come from teaching and research institutions in France or abroad, or from public or private research centers.
L'archive ouverte pluridisciplinaire HAL, est destinée au dépôt et à la diffusion de documents scientifiques de niveau recherche, publiés ou non, émanant des établissements d'enseignement et de recherche français ou étrangers, des laboratoires publics ou privés. 


\title{
THE DEVELOPMENT AND COMMERCIALIZATION OF SOLAR PV TECHNOLOGY IN THE OIL
} INDUSTRY

\author{
Jonatan Pinkse ${ }^{\mathrm{a}, \mathrm{b}}$ \& Daniel van den Buuse ${ }^{\mathrm{b}}$ \\ ${ }^{a}$ Grenoble Ecole de Management \\ ${ }^{\mathrm{b}}$ University of Amsterdam Business School
}

Energy Policy, 40(1), 11-20

\begin{abstract}
In diversifying energy supply, the transformation of the energy industry has been identified as a key challenge for a sustainable energy future. This suggests that incumbent firms in this industry have a vital role in the development and commercialization process of renewable energy technologies. This paper provides a comparative analysis of oil and gas firms' strategies regarding solar PV technology investments, a renewable energy technology that has seen explosive growth of late. The main aim is to examine the strategic approach of incumbent firms in the oil and gas industry towards the development and commercialization of solar PV technology. To investigate this, a multiple case study has been conducted within the European oil industry, focusing on the three largest oil and gas firms: BP, Royal Dutch/Shell, and Total. Findings show that oil and gas firms have difficulties with integrating solar PV technology in their supply chain. The analysis suggests that it is uncertain whether all oil and gas firms will abandon solar completely, as this depends to what extent they are able to generate profits. Nevertheless, there is currently a trend in the oil industry of leaving solar and positioning towards a 'recarbonization' of business activities.
\end{abstract}

Key words: renewable energy, solar photovoltaic, oil and gas industry

Correspondence: Dr. Jonatan Pinkse; Grenoble Ecole de Management; 12 Rue Pierre Semard; 38000 Grenoble; France; E-mail: jonatan.pinkse@grenoble-em.com 


\section{THE DEVELOPMENT AND COMMERCIALIZATION OF SOLAR PV TECHNOLOGY IN THE OIL}

\section{INDUSTRY}

\section{Introduction}

The path towards achieving sustainability in energy supply on a global scale is one of the key challenges for the twenty-first century. Since the industrial revolution, industrialized societies worldwide have had a consistent dependence on fossil energy sources to achieve economic growth. This dependence on fossil energy sources is still reflected in the global energy market at present. However, concerns about global climate change and energy security, particularly due to a high dependence on oil, have put pressure on governments to diversify their energy supply. In diversifying energy supply, the transformation of the energy industry has been identified as a key challenge for a sustainable energy future (Holdren, 2006; Jacobsson and Bergek, 2004; Jacobsson and Johnson, 2000; Unruh, 2000). This suggests that incumbent firms in this industry have a vital role in the development and commercialization process of renewable energy technologies.

When looking at the key high-potential renewable technologies for widespread diffusion, wind energy is the most developed renewable technology. With an average annual growth rate in installed wind power capacity between 1980 and 1998 of 55\% (Jacobsson and Johnson, 2000), and an average annual growth rate of 25\% from 2002 to 2006 (REN21, 2008), wind energy has reached a cost-competitive level with fossil fuel-based energy technologies, and is the most widespread renewable energy technology (Gross et al., 2003). Contrary to the mature development stage of wind power, solar photovoltaic (PV) technology is an emerging technology, which grew relatively slow in the1990s, i.e. 22\% annually (Jacobsson and Johnson, 2000). However, from 2000 onwards, investments in solar PV capacity have increased considerably, even leading up to an annual growth rate of $70 \%$ in grid-connected solar PV instalments in 2008 (REN21, 2009), and has thus become the fastest growing energy technology worldwide.

With this global momentum in the growth of solar PV technology, a major avenue emerges to analyze the strategic approach of incumbent firms in the energy industry towards the development and commercialization of solar PV technology, as their powerful position in the industry might give them a pivotal position in the diffusion process of solar PV. The main aim of this paper is therefore to provide a comparative analysis of oil and gas incumbents' strategies regarding the development and commercialization of solar PV technology. To investigate this, we have conducted a multiple case study within the European oil industry to compare and contrast the three largest oil and gas firms - BP, Royal Dutch/Shell and Total - with regard to their perception of renewable energy technologies in the context of future energy supply as well as their investment behaviour in solar PV technology from the 
mid-1990s onwards. Before exploring these aspects empirically, however, we will first briefly provide a background on the diffusion process of renewable energy technologies.

\section{Towards the diffusion of renewable energy technologies}

Renewable energy has the potential to replace conventional fuels in four distinct sectors: power generation (grid-connected), transport fuels, water and space heating, and rural (off-grid) energy (REN21, 2008). As each of these energy sectors has its own characteristics, a renewable energy future is unlikely to depend on a single prevailing 'silver bullet' technology ending fossil fuel dependence. Instead, a wide spectrum of various renewable technologies will be more suitable for meeting the diverging demands of each of these four sectors. As Gross et al. (2003) identify, one of the most notable features of renewable forms of energy is the diversity of technologies, thereby indicating that renewable energy diffusion will lead to diversification in energy sources making energy markets less dependent on fossil fuels as a single source of energy.

Experimentation with various renewable energy sources on a non-commercial basis commenced around 1973, when governments started investing considerable amounts of money on renewable energy research and development $(R \& D)$ as a reaction to the first major oil crisis in that same year (Jacobsson and Johnson, 2000). Since the early 1990s, commercial development of various forms of renewable sources has occurred, resulting in a range of modern renewable technologies of which solar PV, wind power, concentrating solar power (thermal and PV), marine power (wave and tidal), and modern biomass offer the best opportunities for widespread diffusion. Conventional renewable sources, predominantly traditional biomass and large hydroelectric installations, supplied around $17 \%$ of the world's energy demand around the start of the century, but do not offer significant sustainable growth opportunities towards the future (Gross et al., 2003). Although modern renewable technologies currently account for only $1 \%$ of the world's energy demand, projections of their contribution in meeting the world's energy demand around 2050 range from $20 \%$ to $50 \%$ (World Energy Assessment, 2000).

Embedded in the larger development of moving from fossil fuels to renewable technologies, solar PV has emerged as the fastest-growing technology in recent years with huge diffusion potential towards the future. The first commercial efforts to develop solar PV technology were initiated by the oil crises of the early 1970s, with governments investing in R\&D to develop a solar alternative to fossil fuels (Tsur et al., 2000). However, these policies for stimulating solar investments lacked a long-term perspective and were strongly correlated with fossil-fuel price fluctuations. With fossil-fuel prices decreasing in the mid 1970s, investments in solar R\&D decreased tremendously, with technological development only continuing for several smaller niche markets. From the mid-1980s to mid-1990s solar PV capacity started to grow with a modest growth rate of $15 \%$ (Gross et al, 2003), 
with an increasing importance for grid-connected systems after 1995 (World Energy Assessment, 2000). Influenced by an increasing awareness of issues such as energy independence and negative environmental consequences (e.g. climate change) of fossil fuel combustion in the early 1990 s, R\&D investments became more centred on developing a long-term-oriented alternative to fossil fuels compared to the 1970s. Investments in solar PV increased extensively after 2000 due to increased cell efficiency, reduced capital costs, and favourable policy, leading to annual growth in grid-connected solar capacity of $60 \%$ from 2002 onwards (REN21, 2008).

The most vital component of solar PV technology is the solar cell, as the solar cell establishes the photovoltaic effect and therefore determines the conversion efficiency. Growth potential of solar PV essentially depends on two aspects: the achieved conversion ratio in the solar cell and the capital costs (installation and materials) associated with solar cell production. Solar cell types currently being commercialized are single-crystal cells (17\% efficiency in 2007), polycrystalline (15\% efficiency in 2007) and amorphous silicon (10\% efficiency in 2007), which all are considered to be the first generation PV technologies. These technologies require major energy and labour inputs, which prevent significant production costs reductions, but are currently the most-installed type of solar cells (REN21, 2008). Second generation solar cells offer much greater potential for cost reductions and efficiency enhancement. These are thin-film cells that currently offer only 9-12\% efficiency, but are in an early development stage with extraordinarily high potential for conversion ratios up to $60 \%$, compared to $30 \%$ for first generation cells. In 2007 , only $7 \%$ of solar cell production was thin-film cells, but they gained acceptance as a mainstream solar cell due to manufacturing maturity and decreased production costs. Despite this acceptance, conversion ratios are far from their potential, making it more viable to further invest in $\mathrm{R} \& \mathrm{D}$ before large-scale commercialization will take place (REN21, 2008). Goetzberger et al. (2002) define three scenarios for cell efficiency enhancement and cost reductions: (1) the continued dominance of present single-crystal and polycrystalline cells, (2) the introduction of new crystalline thin-film materials of medium thickness, and (3) the breakthrough of true thin-film materials that could potentially dramatically increase cell efficiency. All scenarios are equally plausible on the long term, although the first and second generation solar cells are more shortterm oriented and currently visible in the market, while third generation is more likely to occur in a longer timeframe (Gross et al., 2003).

From an industry life cycle perspective, two main phases in industry evolution can be identified: a formative period and a market expansion period (Jacobsson and Bergek, 2004; Klepper, 1997; Utterback and Abernathy, 1975). The formative period is characterized by uncertainty in technologies, markets, and regulations, whereby a range of competing technology designs exist. Within this formative period, Jacobsson and Bergek (2004) identify four process features: market formation, entry of firms and organizations, institutional change, and the formation of technology- 
specific advocacy networks. All four features are beginning to emerge in the solar PV industry, whereby the first two are especially interesting in the light of this paper. Market formation is characterized by growth in multiple niche markets for which the technology is superior, usually also involving favourable government policy and investment incentives. It appears that the solar PV industry entered its market formation stage around 2004, when favourable policy towards solar PV became more widespread and solar PV was developed for multiple grid-connected and off-grid niche applications. This phenomenon is referred to as 'protected spaces' or niches, where technological learning process can take place, and where price of performance of the technology can be improved (Jacobsson and Bergek, 2004; Kemp et al., 1998).

Three factors are particularly important in this industry's formative period. First, solar cell efficiency and capital cost reduction for large-scale diffusion need to be achieved (Goetzberger et al., 2002; Gross et al., 2003; REN21, 2008). Second, policy should be developed to allow development in solar PV niche markets to support the learning effect from 'learning by doing', which positively influences large-scale diffusion of solar PV technology (Gross et al., 2003). Tsur et al. (2000) suggest that this diffusion process should be evolutionary rather then revolutionary in nature, also emphasizing that government-funded stimulating $R \& D$ programs should be adopted that are substantial and persistent in nature. Third, firm entry is essential in shaping the development path of an emerging technology, predominantly due to the resources and competences they bring into the industry (Jacobsson and Bergek, 2004). With solar PV growing tremendously, and huge opportunities for firms from various backgrounds to enter this growing market, assessing the impact of businesses on solar PV development is therefore essential.

\section{Solar PV diffusion in the oil industry: a research model}

To investigate the behaviour of incumbent firms in the oil and gas industry regarding solar PV development and commercialization, we applied a multiple case study methodology. This methodology facilitates gaining rich understanding of the context in which the phenomenon is embedded (Yin, 1994). In this paper, the unique phenomenon is the emergence of a renewable energy technology in the oil and gas industry, which is fundamentally different from the fossil fuel-based technologies that are currently widely diffused in the supply chains of large oil and gas incumbents. As our sample we chose three major players in the European oil and gas industry, which have made 'substantial' investments in solar PV in the recent past: BP, Royal Dutch/Shell and Total. We collected data about corporate behaviour on solar PV development and commercialization from both corporate and independent third-party sources, thereby assessing whether the articulated corporate position of these firms on the importance of solar PV technology was in line with perceptions from outside. Data collection included corporate publications (i.e. firm annual reports and 
CSR/sustainability reports), publications of trade associations (i.e. the European PV Industry Association, the Energy, Solar Energy Industries Association, and the Solar Electric Power Association), and newspaper and magazine articles (i.e. New York Times, Wall Street Journal, Washington Post, Guardian, Economist, and Time magazine).

To guide the analysis of the data, we first developed a research model (see figure 1). Our starting point was the assumption that the emergence of solar PV technology in the established oil and gas industry presents incumbent firms with a fairly disruptive technological innovation. Literature on the emergence of disruptive innovations shows that small entrepreneurial ventures provide the more heterodox, breakthrough innovations, while incumbent firms generally engage in incremental, sustaining innovations to optimize technology performance (Baumol, 2002; Bower and Christensen, 1995). At the same time, however, the bulk of expenditures in R\&D and related innovative activities, are not carried out by small entrepreneurial ventures but by large oligopolistic firms (Ahuja and Lampert, 2001; Baumol, 2002). With the model we therefore envisaged gaining understanding of how incumbent firms can stimulate the development and commercialization of disruptive technological innovations, including the use of acquisitions and joint ventures as ways to gain control over disruptive innovations, rather than gaining insight into how small entrepreneurial ventures introduce new innovations and organically grow into larger corporations.

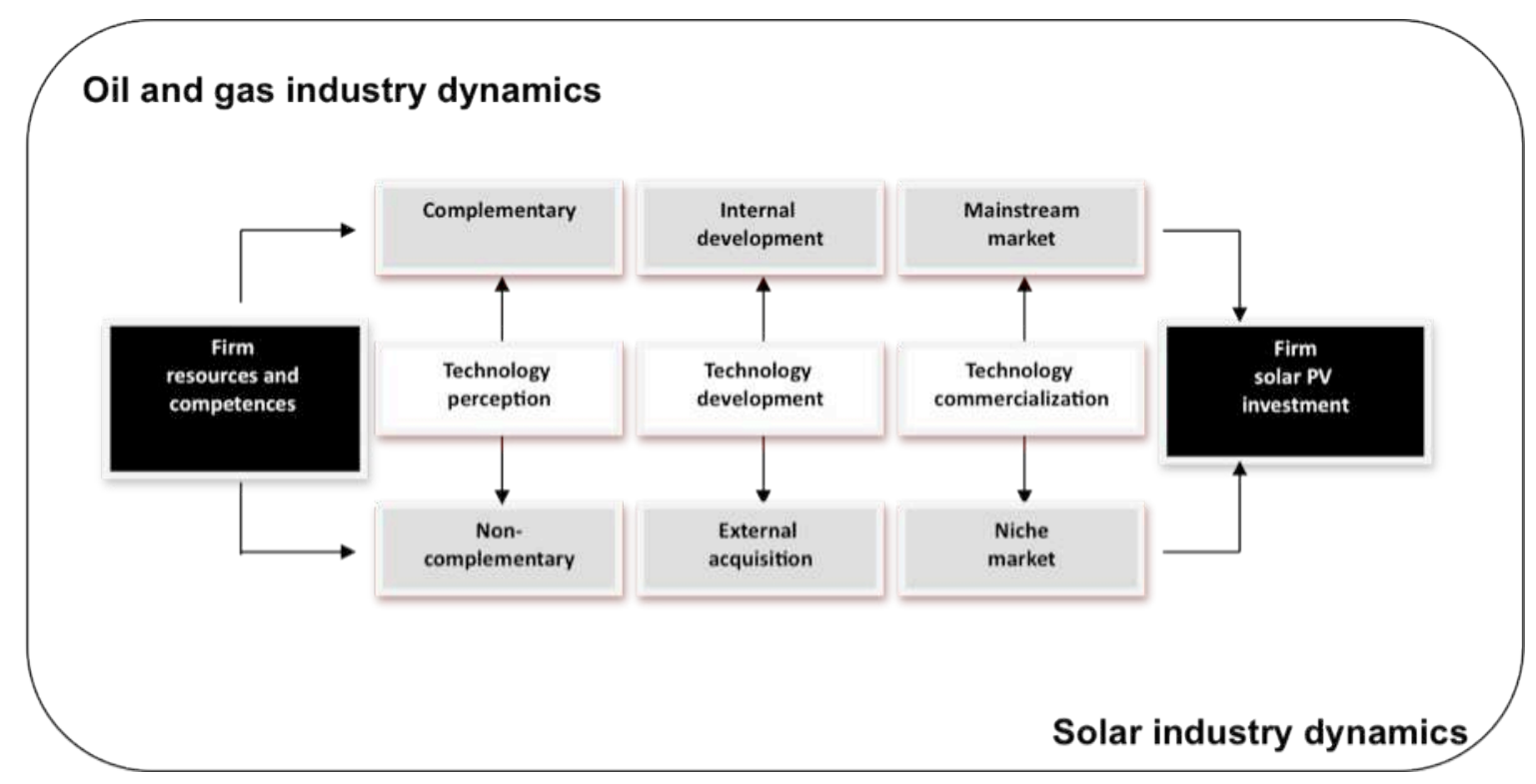

Figure 1 Solar PV technology diffusion: a research model

The model is built around the innovation process of firms, which comprises the invention and development of a technology as well as the commercialization in the market. This process requires various resources and competences such as technology accumulation, strategic networking through 
alliance formation, and being responsive to market needs (Rothwell, 1994). The central notion in the innovation process is that firms make strategic decisions and position themselves on renewables taking account of firm-specific factors to leverage internal resources and competences as well as contextual factors to anticipate external industry dynamics (Kolk and Levy, 2004). We considered firm-specific factors related to development and commercialization decisions along the following steps in the innovation process: (1) what is the strategic nature of solar PV technology in relation to firms' core business goals; (2) what is the incumbent's strategy towards the development of the emerging technology; and, (3) what is the incumbent's approach for commercializing the emerging technology? In answering these questions, we also reckoned with contextual factors related to industry dynamics, where we made a distinction between oil and gas industry dynamics and solar industry dynamics. The motivation behind this is that oil and gas firms investing in solar technology operate at the intersection of both industries. Therefore, contextual factors not only concern those affecting market formation in the solar industry, but also factors shaping the oil industry's market structure. While some factors such as oil price changes or the global financial crisis have an effect on dynamics in both industries, other factors such as renewable energy policy or firm entry/exit are more industry-specific.

Firstly, the model posits that the strategy of oil and gas firms in solar PV diffusion depends on oil and gas incumbents' perception of solar PV technology in terms of degree of complementarity to core business activities (Davis, 2006; Milgrom and Roberts, 1990). The concept of complementarity refers to the relation between different business activities such as $R \& D$, manufacturing and marketing which firms pursue, implying that a fit between activities leads to higher economic returns (Milgrom and Roberts, 1990; Jacobides et al., 2006). Whether the development, manufacturing and marketing of solar PV have many complementarities with core business activities of oil and gas firms is contestable. Throughout the vertically integrated supply chain of oil and gas firms, the resources and competences needed to operate both upstream and downstream activities are related to fossil-fuel supply (Davis, 2006). Therefore, on the face of it, a disruptive technology such as solar PV cannot build on existing attributes related to upstream extraction activities and downstream refining, which are (still) crucial for the oil and gas industry, but introduce a new set of attributes that potentially depreciate the value of the attributes historically valued by mainstream customers (Bower and Christensen, 1995). The main problem is that solar PV requires much corporate R\&D to achieve cost-effectiveness of the technology. However, R\&D investments in the oil industry have predominantly been aimed at refining and petrochemicals; R\&D budgets have decreased considerably; and these investments have exhibited relatively low rates of return (Davis, 2006). Solar PV technology would thus mean that activities throughout the whole supply chain have to change fundamentally, which would require 
different resources and competences than currently owned by oil and gas firms (Kolk and Pinkse, 2008).

Nonetheless, it is not uncommon either for firms to invest in technologies, which are not complementary to core business activities. Besides investing in sustaining technologies, incumbents also invest in disruptive technologies for reasons of diversification and exploration of potential future growth markets (Bower and Christensen, 1995). Whether the oil industry considers renewable energy as a future growth market has differed considerably across firms (Levy and Kolk, 2002), and even within firms the outlook changed over time, depending on how various scenarios on the stake of renewables in global energy supply evolved (Backer and Clark, 2008). To what extent oil firms are willing to diversify into solar also depends on the general corporate strategy, which in the case of oil firms has changed considerably over the past decades (Grant, 2005; Grant and Cibin, 1996). After the oil crises of the 1970s, which led to a decline in demand for oil and an emergence of state-owned enterprises, the oil industry has become very turbulent and competitive. In response, oil firms pursued diversification in related and unrelated activities on a massive scale, including solar PV. In the period from the mid-1980s to mid-1990s, however, this trend reversed from diversification to massive restructuring and a focus on core business (Grant, 2005). Due to declining oil prices and increased emphasis on short-term profitability, most non-core activities were divested during this period, but remarkably solar technology was maintained in most large oil firms (Davis, 2006; Grant and Cibin, 1996). In other words, while non-complementarity seemed no real obstacle during the 1980 s, in the 1990s this became more of an issue. Yet, it must be noted that the perception of what core business constitutes also changed during the 1990s, as some companies broadened their mission from 'oil' to 'energy' firms (Kolk and Levy, 2001). Still, when a technology is perceived strategically significant but non-complementary, firms will most likely locate the initial market for introducing the disruptive technology outside existing mainstream markets that incumbents serve and set up an independent organization, isolated from core activities (Bower and Christensen, 1995).

Secondly, the strategy of oil and gas firms for solar PV diffusion depends on the way the technology development is organized, that is, whether they opt for internal development or external acquisition. As mentioned above, in the technological development of solar PV, solar cell development is the key element where innovation takes place and two elements are crucial for the potential for large-scale diffusion: solar cell efficiency and capital cost reduction (Goetzberger et al., 2002; Gross et al., 2003). But, how do oil and gas firms achieve such scale effects when solar PV lies outside oil and gas firms' major innovation activities? The fact that solar PV seemingly lacks complementarity with core oil and gas activities means that oil firms face the challenge of developing new resources and competences, as they cannot rely on earlier investments in this area. Not surprisingly, in the past, the oil industry has expressed different views on technology development 
paths for solar PV (Levy and Kolk, 2002). It has been posited, for example, that competences in solar PV take time to develop and early investments are necessary to develop scale, learning and complementarities, which corresponds to preference for internal development, enabling these effects to materialize. Alternatively, it has been argued that, since they lack the required competences for solar PV, oil firms should only invest in this technology when the external environment for renewables has become less risky. This view has mainly been fuelled by past experiences in the industry of failed diversification - also in renewable energy - thus leading to preference for external acquisition when the 'time is right' (Davis, 2006; Levy and Kolk, 2002).

There are also potential other reasons for deciding on internal growth versus external acquisition, which are related to the high vertical integration that has traditionally characterized the organization of oil firms (Grant and Cibin, 1996). In the past, oil firms have owed most of their success to controlling the whole value chain. And, even though there was a trend towards vertical disintegration in the 1980s and 1990s, recent expansion in natural gas has again been carried out by covering the complete chain from exploration to marketing (Grant, 2005). However, the vertically integrated firm tends to be equated with a view of incumbent-led technological development devoted to routinized innovation processes for increasing product and process reliability, based on a conservative approach with bureaucratic control (Baumol, 2002, p. 6). Moreover, this way of organizing has been portrayed as 'closed innovation', where incumbents generate, develop, and commercialize their own ideas and innovations, based on a philosophy of self-reliance in which innovation activities are based on control and substantial investments in internal $R \& D$ (Chesbrough, 2003). Recently, however, a fundamental shift has been observed in the process of how firms generate ideas, develop innovations, and commercialize these ideas and innovations to the market from closed to open innovation. In 'open innovation', an organization 'commercializes both internally and externally developed innovations, by deploying both outside and in-house pathways to the market' (Chesbrough, 2003, p. 37).

For the development and commercialization of solar PV technologies, the philosophy of selfreliance underlying the closed innovation model will be complex; oil and gas firms cannot rely on historical R\&D investments in this area, and achieving intra-firm complementarities between solar PV and oil and gas activities is intricate. In contrast, applying the concept of open innovation to solar PV technology development and commercialization seems sensible as incumbent firms can commercialize solar PV technology outside their own supply chain, and develop inter-firm complementarities instead (Davis, 2006). Even so, what will be crucial, then, in determining how oil and gas firms develop solar PV technology, is a firm's financial investment power. If, therefore, financial investment power through generated income is exceptionally strong, which is usually so 
when oil prices are high, they will most likely use this to externally acquire solar technology and knowledge, rather than develop it internally.

Thirdly, when it comes to commercialization of solar PV technology, the focus is on downstream activities in the supply chain, particularly the distribution, marketing and sales activities to deliver energy to customers. The main question is whether market penetration in mainstream markets is possible or firms can merely establish one or more market niches (Raven, 2007). For oil and gas firms, all end-product categories (light, medium, and heavy distillates) are fully based on fossil fuel supply. Both end-users in the industrial market and consumer market rely on the supply of fossil fuels which are currently non-substitutable, as this would require a major technological shift in various fossil fuel-based industries, such as steel, chemicals, and construction as well as in consumer behaviour regarding transportation. In other words, the fossil fuel dependence of end-users also enforces the carbon lock-in of this industry (Unruh, 2000). Therefore, key downstream activities of oil and gas firms do not really fit solar energy supply. Then again, solar PV does give oil firms the opportunity to enter new niche markets, which is enhanced by the fact that solar PV is a modular technology that can be fairly easily integrated into final consumer products (Davis, 2006).

Moreover, comparing the emerging solar market with the mature oil and gas market provides a false picture of the commercialization potential of solar PV. To assess the potential for large-scale commercialization, it is more useful to consider the solar PV market in isolation and compare different niches within this market. For example, there are important differences between gridconnected and off-grid solar systems in their potential for mass production. Grid-connected systems are more suitable for mass production compared to off-grid applications, because the latter often require on-site customization and alternative business models to reach the customer (Shum and Watanabe, 2007). Nevertheless, grid-connected solar systems have the disadvantage that they have to compete directly with other electricity generation technologies, whereas off-grid applications are more often implemented in developing countries with inadequate of lacking electricity infrastructures (Davis, 2006). Another case in point regarding large-scale commercialization of solar PV is the role of government-initiated investment stimulation for solar PV technology. Feed-in tariffs implemented during the 2000s, which have particularly been successful in Germany and Spain, have stimulated the creation of markets for solar PV (Jäger-Waldau, 2009). Still, whether oil firms could benefit from these energy policy measures depends much on the precise their provisions (Reiche and Bechberger, 2004). 


\section{Solar PV in the oil and gas industry}

\section{British Petroleum}

In comparison to other oil and gas firms, $\mathrm{BP}$ has the longest history in the development and commercialization of solar energy, with BP's first solar activities dating back to 1980, and BP's establishment as the world's largest vertically integrated solar PV firm in 1999. Within BP, PV technology was built as a separate product class from 1980 onwards, which eventually led to the establishment of a separate BP Alternative Energy division in 2005. The growth process of BP Solar towards its current position as one of the larger solar companies worldwide has thus been achieved by setting up a separate solar division outside existing fossil fuel-based activities to cope with a technology that is potentially disruptive. Nevertheless, the fact that BP entered the solar industry at such an early point in time, and has consistently built its position in the market, indicates that BP perceived the technology as strategically important.

The first milestone in BP's solar activities was in 1980, when BP entered the solar market through the acquisition of solar company Lucas Energy Systems. This step was part of a broader diversification strategy (BP for example also entered the coal business, minerals and information technology), then common in the oil industry, as it was a response to the 1970s oil crises and slowing growth (Grant and Cibin, 1996). A second milestone was the speech of BP chief executive John Browne at Stanford University in May 1997, where he pledged to increase investments in solar from $\$ 100 \mathrm{~m}$ to $\$ 1 \mathrm{bn}$ a year. Interestingly, this commitment to solar was no longer considered as diversification, but part of a strategy to be responsive to the issue of climate change (Levy and Kolk, 2002; Sæverud and Skjærseth, 2007). This pledge was followed up in 1999, when BP Solar established itself as the largest vertically integrated solar company in the world, through the acquisition of all of shares in Solarex (a company made up of former solar activities of Exxon, Enron and Amoco), creating BP Solar as it exists at present. Although BP perceived solar technology as disruptive, at this time it was not necessarily considered as non-complementary. In 2000, BP repositioned its mission from an exclusive focus on oil towards a broader focus on energy, which was accompanied by a rebranding campaign with the Helios logo and the 'Beyond Petroleum' slogan as main outcomes (Kolk and Levy, 2001).

What is remarkable about BP Solar is the different perception of crystalline solar technology in comparison to thin-film technology. Until 2002, BP had a strong position in crystalline technology in both manufacturing and sales, but simultaneously engaged in innovation of thin-film technology. In 2002, BP decided to abandon further developing thin-film technology and focus solely on crystallinebased technology, based on the rationale that thin-film in its 2002 development stage was economically uninteresting. BP Solar's consistent commitment to crystalline-based technology was enforced in 2006 when BP invested $\$ 5 \mathrm{~m}$ to a five-year research project on The California Institute of 
Technology, to develop a more efficient way of producing crystalline solar cells making solar manufacturing costs more competitive. BP Solar's decision to consistently build a position in crystalline solar cells and not engage in thin-film technology is noteworthy, because crystalline-based technology has limited possibilities for radical performance enhancement (Goetzberger et al., 2002; Gross et al., 2003).

A consistent and crucial factor for BP's development of solar technology has been its engagement in acquisitions and joint ventures. BP achieved growth in its solar business in the 1980s and 1990s by building a global network of manufacturing facilities, mainly through acquisitions of existing solar manufacturing plants, and sales offices in multiple countries, most notably the abovementioned acquisitions of Lucas Energy Systems and Solarex. Besides acquisitions, BP also engaged in joint ventures to gain access to specific geographical markets. In 1989, BP entered a joint venture with Tata Energy to establish its position in the Indian market, while in 2005 BP Solar partnered with China-based solar company SunOasis to build its position in the Chinese market. A key observation regarding technology development is BP's consistent focus on achieving scale advantages to reach cost-competitiveness with widely diffused energy technologies, both in manufacturing activities and solar power plants. For manufacturing, this already started in 1997, when BP announced investing $\$ 20 \mathrm{~m}$ to establish one centralized manufacturing plant for the US market, and was continued until 2008, when BP decided to focus manufacturing activities on the four largest plants in the US, Spain, China and India. Regarding solar power plants the focus on scale is illustrated by BP's projects in Portugal and Spain in 2005 where it profited from feed-in tariffs: in Portugal BP Solar constructed a large $62 \mathrm{MW}$ power plant of 350.000 solar panels delivering electricity to 22.000 homes, while in Spain BP built 278 small power plants across Spain with a joined capacity of 18 to $25 \mathrm{MW}$, thereby providing electricity to 12.500 homes.

When assessing commercialization, the acquisitions and joint ventures also point at BP's external focus in the context of marketing solar products. In building its position in the solar market, BP followed a strategy of entering multiple niche markets while simultaneously improving crystalline technology. In the context of BP Solar's leading position in the global solar industry and the vertically integrated nature of the company's solar activities since the 1999 takeover of Solarex, BP Solar has become a mainstream player in the solar industry. To illustrate, in 2001 BP had become the second largest solar PV firm with annual sales of 58 megawatts (MW). Nevertheless, even though BP Solar's sales climbed steadily over the years its leading position declined from being number 2 in 2002 (73.8 MW) to number 7 in 2005 (90 MW) and number 16 in 2008 (156 MW), as it was surpassed by specialized solar firms including Q-Cells, Suntech and First Solar (Jäger-Waldau, 2002, 2003, 2006, 2009). 
The focus on controlling costs seems crucial when looking at the most recent developments in BP Solar. The financial crisis and economic recession negatively affected the position of BP Solar, which translated into major cost reductions through cutting $28 \%$ of BP Solar's workforce, predominantly in the US and Spain. Not surprisingly, BP recently decided to subcontract solar panel manufacturing to China and India, dismantling the vertically integrated solar firm, and only retain those activities where value can be created. In addition, with BP Alternative Energy making a loss of $\$ 800 \mathrm{~m}$ in 2008, while BP as a whole was profitable, the announced budget cuts in BP Alternative Energy of at least $\$ 400 \mathrm{~m}$ for 2009 , and BP's recent investment in upstream activities that include winning oil from Canadian tar sands (BP, 2008, p.5), it is of vital importance to reach costcompetitiveness for solar PV technologies within a limited timeframe. Within BP a lack of profitability of renewable energy technologies could thus be a strong driver for divestiture decisions.

\section{Royal Dutch/Shell}

In its approach towards solar technology, not only has Royal Dutch/Shell long been a follower of BP, but also more modest, applying a lower public profile (Levy and Kolk, 2002). Shell also started investing in solar in the 1980s as part of a diversification strategy (Eikeland et al., 2004; Grant and Cibin, 1996), but on a much smaller scale. The first real milestone for Shell was in October 1997, when it committed to investing $\$ 250 \mathrm{~m}$ in its solar manufacturing over the next five years. This was considered a way of repositioning the firm on climate change as well as a response to BP's recent shift on the issue (Levy and Kolk, 2002). What is particularly noteworthy about this commitment is that investments in renewable energy were heralded as Shell's 'fifth core business' (Boulton, 1997). However, over the past years Shell's stance towards solar PV has become more reserved and the firm has recently reiterated that the primary focus is upon sustaining reliable and responsible fossil energy supply (Shell, 2008). According to former Shell CEO Van der Veer, Shell expected around $80 \%$ of all the firm's capital investments to be in upstream projects (Shell, 2008). With respect to the importance of renewable energy technologies for Shell, CEO Van der Veer stated in the 2008 sustainability report (2008, p.1): 'While our primary focus continues to be delivering oil and natural gas responsibly, we also made progress developing renewable energy.'

Compared to BP, Shell's investment and divestiture decisions in solar PV have been poised in uncertainty and exhibited a rather erratic pattern with sudden changes in perceived prospects of solar as a future growth market (Backer and Clark, 2008). However, already when Shell started showing a renewed interest in the solar business in 1997, the firm was relatively cautious in its statements about the future outlook of solar, emphasizing that it would position it as a supplement to its oil and gas business, not as a substitute. In other words, Shell has always perceived solar technology as potentially disruptive and non-complementary to mainstream oil and gas activities, as reflected by the 
fact that Shell's renewables division was neither embedded in the fossil fuel-based supply chain nor focused on serving Shell's mainstream customers in Shell's oil and gas business. From its conception, Shell Solar was integrated in the Shell Renewables division, which in turn was as a separate division outside existing divisions of upstream (exploration \& production and gas \& power) and downstream (oil products, oil sands, and chemicals) divisions.

Reticence towards investing in solar PV has culminated in a series of divestitures, which started with selling all crystalline activities in 2006 to Solar World, as Shell perceived this technology as economically uninteresting for large-scale diffusion. This continued until the final decision in 2009 to divest all renewable technologies including solar, wind and hydrogen. A statement of Shell on the rationale for divesting most renewable energy technologies while investing in biofuels is a case in point: 'Shell will be stepping up efforts in sustainable sourced transport biofuels as the area of focus for renewable energy activities, as biofuels are closest to our fuel business, which means Shell can add real value' (Shell, 2008, p. 10). The fact that biofuels can be integrated into the supply chain is a key determinant for Shell to further invest in this form of renewable energy. Despite pulling out of renewable technologies, Shell not only announced to increase investments in its bio-fuels activities, but also to concentrate on developing cleaner ways of using fossil fuels through carbon capture and storage (CCS). In other words, as a way of coping with climate change, CCS is more attractive than other renewables including solar because it allows continuation of fossil fuel supply with lower emissions (Pinkse and Kolk, 2010), but was not yet available when climate change became salient to the oil industry in the 1990s.

Moving to Shell's strategy for developing solar PV technology, the joint venture structure that Shell Solar adopted for technology development between 2001 and 2006 shows that Shell focused on the external acquisition of complementary resources and competences for solar PV development; reasonable since Shell's innovation capacity is in fossil fuel technologies, with $80 \%$ of all technology innovation expenditures going to fossil fuel-based upstream technology development (Shell, 2008). First, in 2001, Shell Solar (33\%) entered a joint venture with Siemens (34\%) and E.ON (33\%) for technological innovation in crystalline-based cell technologies. In 2002, through the acquisition of $100 \%$ of the shares in the Shell-Siemens-E.ON joint venture, Shell established access to both monocrystalline and multi-crystalline cell technologies, then mainstream solar technologies, and thin-film technology, which was in an early development stage in 2002. After this acquisition, Shell had transformed Shell Solar into a vertically integrated solar company, which included R\&D, manufacturing and marketing of solar PV (Jäger-Waldau, 2004). Second, in 2006, after selling all its crystalline-based activities to Solar World, Shell again entered a joint venture with Saint-Gobain, to develop the next generation thin-film based solar cell in AVENCIS. Although both joint ventures were with incumbent firms and cross-industry in nature, an interesting difference between the Shell- 
Saint-Gobain joint venture in 2006 and Shell-E.ON-Siemens joint venture in 2002 is the difference in industry of Shell's joint venture partners. However, a more important observation in this context remains Shell's engagement in joint ventures with incumbent firms instead of small technology-based entrepreneurial ventures.

Looking at the commercialization of solar PV, in the initial growth phase between 1997 and 2001, Shell Solar served two distinct markets: grid-connected solar systems and rural electrification. In the context of energy supply, both markets were niche markets compared to other technologies for electricity generation, and both markets were outside Shell's existing oil and gas business, yet becoming mainstream within the solar industry. Simultaneously, as of the Shell-Siemens-E.ON joint venture, focus has come on innovating in crystalline solar PV technology; the most widely diffused solar technology at that time. With Shell's acquisition of all shares in that joint venture in 2002, Shell gained access to a global network consisting of professional distributors and sales partners with sales offices worldwide for mono-crystalline, multi-crystalline cell and thin-film technologies; thus steadily building its position in multiple niche markets. The growth in multiple niche markets led Shell Solar to become the second largest solar company in the world in 2003 with $73 \mathrm{MW}$ in sales (Jäger-Waldau, 2004). Initially Shell appeared to be on a path of commercializing solar PV beyond niche markets to larger and broader mass markets. With the 2006 Shell-Saint-Gobain joint venture for the development of thin-film based CIS technology, and the divestiture of crystalline-based activities in that same year, Shell appeared to be seriously building its position in solar PV technology even further through developing a new generation solar cell suited for large-scale diffusion. However, with the 2009 decision to abandon all solar activities, it has become clear that at present Shell has no intention to further develop solar PV technology into mainstream markets.

\section{Total}

In contrast to BP and Shell, Total has only become a 'supermajor' quite recently, after it merged with PetroFina in 1999 and Elf Aquitaine in 2000, which was part of the wave of mergers occurring in 1995-2002 period (Grant, 2005). Moreover, for a long time, Total was a state-owned enterprise and even after the French government reduced its stake; it has maintained close relations with Total (Buchan and Mallet, 2001; Van de Wateringen, 2005). Presumably, due to Total's distinct history of becoming one of the largest oil firms while being state-owned first, it has been a relative latecomer in the solar business. At any rate, at the end of the 1990s, when BP and Shell renewed their investments in solar, Total was not under the same kind of pressure from non-governmental organizations to deal with climate change, because it was still fairly small and to some measure sheltered by the French government (Buchan and Mallet, 2001). Nevertheless, although Total had made some small investments in solar in the 1980 s, it entered the solar market in a significant way in 2001 , but on a 
smaller scale than BP and Shell (Eikelund et al., 2004), and has stayed active ever since. Total has built its position in solar energy consistently through subsidiaries by engaging in joint ventures and acquisitions. Total has also perceived solar PV technology as disruptive and lacked the resources and competences to build its position in solar energy through internal development, and thus opted for 'open innovation' and the creation of inter-firm complementarities instead (Davis, 2006). However, contrary to Shell and BP, Total does not have a separate renewable/alternative energy division as an autonomous business unit in the company.

For the establishment of Total's subsidiaries in the solar PV industry, joint ventures and acquisitions have been Total's consistent investment strategy. In 2001, Total entered the solar industry with the $€ 14 \mathrm{~m}$ joint venture Photovoltech - Total (47.8\%), GDF Suez (47.8\%), IMEC (4.4\%) - aimed at $\mathrm{R} \& \mathrm{D}$ and production on multi-crystalline silicon solar cells, which has shown consistent growth over the years towards revenues of $€ 67 \mathrm{~m}$ (48 MW) in 2008. Subsequently, in 2005 Total together with EDF invested in the acquisition of $50 \%$ of the shares each in Tenesol, thereby gaining shared control of the solar joint venture. Tenesol is a vertically integrated solar company founded in 1983 with main solar activities in design, manufacturing, installing and operating solar PV systems related to grid-connected applications, electrification of remote sites, and electrification in developing countries. In 2004, Tenesol had sales of $€ 115 \mathrm{~m}$ (25 MW), but has achieved major growth over the years towards projected revenues in 2009 of $€ 300 \mathrm{~m}$ ( $85 \mathrm{MW}$ ). Furthermore, Total invested in a $25 \%$ interest in Novacis in 2007, which conducts R\&D in thin-film photovoltaic cells, and in 2008 made a $€ 45 \mathrm{~m}$ investment in Konarka, a world's leading company in organic photovoltaic technology. While Photovoltech and Tenesol focus on manufacturing and sales of crystalline technology, which is in a mature phase of technology development, Novacis and Konarka focus more on R\&D of a thin-filmbased and organic-photovoltaic-based new generation solar cell, indicating that Total focuses both on commercializing current solar cell technologies and developing future solar cell technologies.

The latter illustrates Total's strategy on the development of solar PV, and is consistent with the following quote of Total scientist Minster, who states that 'with respect to new energy technologies, Total believes these solutions are a long way from maturity. That means Total has to actively pursue a host of technological options, so that when the time comes Total is ready to industrialize the ones that do reach maturity' (Total, 2007, p. 15). When looking at the type of firms in which Total has acquired shares to develop solar PV - Novacis and Konarka - these are both smalltechnology driven ventures with a scientific background. Konarka is illustrative in this context, as the company was established in 2001 by a team of scientists, and technical innovations of the venture have led to investments of over $\$ 150 \mathrm{~m}$ in private capital and $\$ 20 \mathrm{~m}$ in government research funding until 2009. This strategy of Total of acquiring small-scale business ventures for developing future 
solar PV technology is also reflected in Total's strategy for commercializing proven solar PV technology.

Total pursues a strategy in solar commercialization of aiming at several niche markets simultaneously through co-ownership in several small ventures by way of joint venture: Photovoltech, which started as a spin-off of IMEC, one of the world's leading research institutes with a strong knowledge-base in photovoltaic research, and Tenesol, which was founded as a solar energy start-up in 1983. For the near future, Total's stake in Photovoltech is most ambitious in trying to achieve scale effects from mass production, as expansion plans encompass a total production capacity of $500 \mathrm{MW}$ in 2012. Nevertheless, even when this production capacity will be used to its full effect, Photovoltech will not be a major player, as the leading solar firms had already surpassed 500MW boundary in 2008 (Jäger-Waldau, 2009). Interestingly, the joint venture partners Total has co-ownership with in managing these ventures are incumbent firms from electric utilities (GDF Suez in Photovoltech, EDF in Tenesol). This cross-industry collaboration between an oil and gas firm and electric utilities illustrates that incumbents from both industries not only perceive their investments in solar ventures as mutually beneficial, but are also uncertain about the prospects of the solar business and therefore prefer a form of risk sharing.

Table 1 Oil firms' investments and divestitures in solar PV

\begin{tabular}{|c|c|c|c|c|c|c|}
\hline \multirow{2}{*}{ Year } & \multicolumn{2}{|c|}{ BP } & \multicolumn{2}{|c|}{ Shell } & \multicolumn{2}{|c|}{ Total } \\
\hline & Investment & Divestiture & Investment & Divestiture & Investment & Divestiture \\
\hline 1980 & $\begin{array}{l}\text { Purchase of Lucas } \\
\text { Energy Systems }\end{array}$ & & & & & \\
\hline 1989 & $\begin{array}{l}\text { Joint venture with } \\
\text { Tata forming Tata } \\
\text { BP Solar }\end{array}$ & & & & & \\
\hline 1997 & $\begin{array}{l}\text { \$20m investment } \\
\text { in US-based solar } \\
\text { PV manufacturing } \\
\text { plant }\end{array}$ & & $\begin{array}{l}\text { Establishment of } \\
\text { Shell Renewables }\end{array}$ & & & \\
\hline 1999 & $\begin{array}{l}\$ 45 \mathrm{~m} \text { investment } \\
\text { in remaining } 50 \% \\
\text { of Solarex and } \\
\text { merging into BP } \\
\text { Solarex (later } \\
\text { renamed BP Solar) }\end{array}$ & & & & & \\
\hline 2001 & & & $\begin{array}{l}\text { Joint venture with } \\
\text { Siemens and E.ON } \\
\text { for crystalline } \\
\text { technology. }\end{array}$ & & $\begin{array}{l}\text { Joint venture with } \\
\text { GDF Suez and } \\
\text { IMEC forming } \\
\text { Photovoltech }\end{array}$ & \\
\hline $\begin{array}{l}2002 \\
2003\end{array}$ & & $\begin{array}{l}\text { Disinvesting thin- } \\
\text { film solar cell } \\
\text { development and } \\
\text { manufacturing }\end{array}$ & $\begin{array}{l}\text { Acquisition of } \\
100 \% \text { share in the } \\
\text { Shell-Siemens- } \\
\text { E.ON joint venture } \\
\text { Start of crystalline } \\
\text { and thin-film solar } \\
\text { panel production }\end{array}$ & & & \\
\hline 2004 & & & Shell Solar and & & & \\
\hline
\end{tabular}




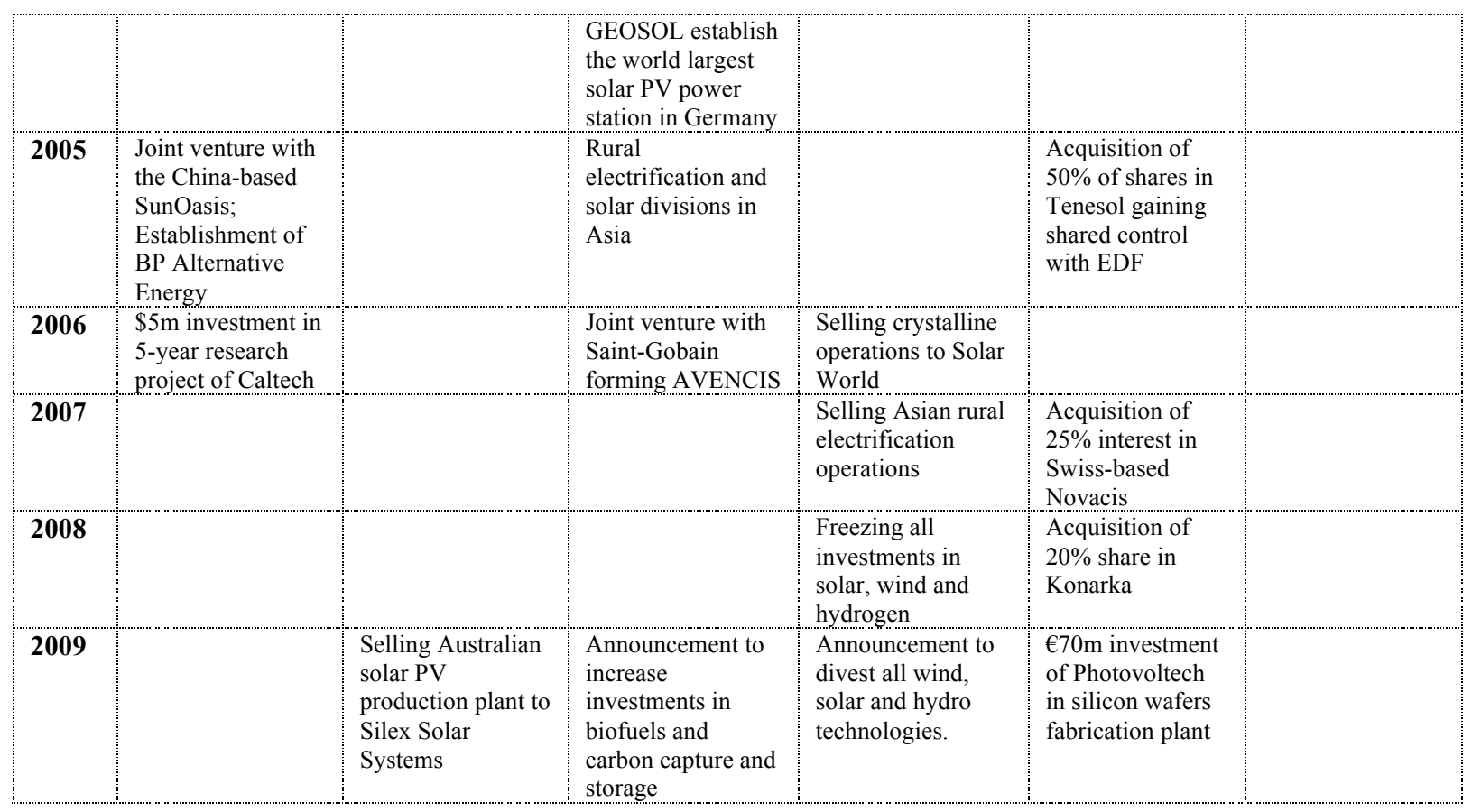

\section{The uncertain outlook of the oil industry's commitment to solar PV: a discussion}

As confirmed by previous research, the major oil and gas firms tend to be fairly similar in the general strategy they follow (Levy and Kolk, 2002), due to the fact that oil industry dynamics are largely determined by geopolitical turbulence, including fluctuating oil prices, energy security issues, climate change, and nationalization of assets. As a consequence, a constant drive for finding new oil reserves has dominated oil firm strategies. Moreover, as the three case firms are currently all 'supermajors' the outcome of an industry which went from large-scale diversification in the 1980s, to a focus on core business in the 1990s, and massive consolidation moving into the 2000s (Grant, 2005) - they share a structure of the vertically integrated firm with divisions in exploration, extraction, refinery, distribution and marketing, indicating that resources and competences are all embedded in supplying fossil fuels. However, although the solar PV investments of these firms over the past decades have exhibited important similarities, there are also clear differences, pointing at divergent views of the future outlook of solar and potential oil industry involvement (see table 1).

Regarding technology perception of solar, Shell, BP, and Total shared the view that solar technology is disruptive and lacks intra-firm complementarities to oil and gas activities. Therefore, these firms built their renewable divisions outside core business activities (Bower and Christensen, 1995), either through separate business divisions detached from the fossil fuel supply chain (Shell Renewables and BP Alternative Energy) or by shared ownership in multiple subsidiaries (Total). Nonetheless, isolating solar activities from core business might also have planted the seed of eventual failure and/or divestiture in Shell and BP. As a separate business unit, it seems difficult for solar to 
survive in an oil and gas firm when subdued to the same performance targets as highly profitable fossil fuel-oriented business units, operating in a mature market. This problem has become larger over time, because a solar business involves investing in a relatively R\&D intensive emerging technology, while performance targets in the oil industry have increasingly emphasized short-term shareholder returns (Grant, 2003). Notably, diversification efforts in the 1980s also revealed problems of non-oil businesses keeping up with profitability targets and they were cross-subsidized to keep them afloat (Davis, 2006). Furthermore, what this implies is that Total's solar activities are not necessarily heading for disaster as well. Total does not have a separate renewable energy division, but invests through multiple subsidiaries co-owned with other firms. In other words, it might be argued that Total, by allowing for interfirm complementarities with electric utilities to evolve (Davis, 2006), has developed solar PV activities which better stand the competition with other business units.

For commercializing solar PV, two distinct markets outside the oil and gas business have been most important: grid-connected solar systems and rural electrification. While both are niche markets in relation to oil and gas markets, they have become mainstream markets within the solar business. To enter these markets and access specific solar knowledge, all three firms relied on financial investment power, using joint venture agreements and acquisitions. However, there are clear differences in the type of firms they acquired or collaborate with, which is related to the fact that there are competing ways to achieve a low-cost, high-efficiency solar cell (Goetzberger et al., 2002; Gross et al., 2003). BP has predominantly focused on acquiring established solar companies, because it made the choice to achieve scale economies based on solar cells using crystalline technology and abandoned its commitment to further develop thin-film technology. At first Shell was following a similar trajectory to achieve scale in crystalline technology, but sold all crystalline activities in 2006 and decided focussing on joint venture agreements with the incumbent Saint-Gobain to further develop thin-film technology. Finally, Total has preferred to keep betting on two horses - crystalline and thin-film - inter alia by setting up joint ventures with large electric utilities and acquiring shares in small technology-driven ventures with specialized knowledge in future generation of solar cells, thus applying open innovation logic (Chesbrough, 2003). However, regardless of whether they have chosen to develop the next generation solar cell with superior performance before investing in commercialization (thin-film technology), or commercialize what was most viable for mainstream markets but limited possibilities for future performance enhancement (crystalline technology), over the past five years oil firms have been outpaced by specialized solar cell producers such as Q-Cells, First Solar, Suntech and Sharp (REN21, 2009). While in 2002 BP and Shell could still be leaders in the solar market with revenues of around $73 \mathrm{MW}$, the solar industry has expanded at an unprecedented pace; in 2008, for example, sales of European leader Q-cells amounted to $570 \mathrm{MW}$, although this firm is now challenged by new entrants from China (Jäger-Waldau, 2009). 


\section{Conclusion and policy implications}

This paper has provided a comparative analysis of oil and gas firms' strategies regarding solar PV technology investments. Our findings show that oil and gas incumbents have experienced difficulties in integrating solar technology in their supply chain and therefore established fairly independent business units, serving niche markets outside mainstream markets for oil and gas. While, on the face of it, it was striking that Shell and BP decided on divestitures of solar at a moment when the technology was on a path towards grid parity, these decisions coincided with a high level of firm entry which led to higher competition in the solar industry. Based on the most recent developments in solar investments, it is nevertheless uncertain whether all oil and gas firms will abandon solar completely, as it depends to what extent they are able to generate profits with these activities.

Furthermore, the findings suggest that the competitive dynamics of oil firms are to a large extent determined outside the market for renewables. However, the competitive strain and increased turbulence in the oil industry have led to erratic investment behavior of oil firms, as various geopolitical factors and short-term performance targets govern the industry. As a consequence, renewable energy projects in which incumbents are engaged might be cancelled for reasons which have nothing to do with the market viability of renewable energy. Nevertheless, due to the economic importance of the industry, oil firms tend to have quite some leverage in advising high-level policy makers on market development for renewables (Backer and Clark, 2008; Jacobsson and Bergek, 2004). This raises the question to what extent it is desirable that policy makers pay lip service to and create incentives for these firms in designing renewable energy policy instruments. An issue for further investigation would thus be a larger study on the influence of oil and gas firms on the emergence and maturing of the renewables industry over time.

In addition, it would also be of interest to study other incumbents with regard to their role in the solar PV industry. For example, while large firms from electronics have already played a role in the development of the solar PV industry, utilities are starting to become more important as well. Firms from these industries might have fewer difficulties creating intrafirm complementarities, but an interesting direction for further inquiry is whether and/or how they are able to create these or face problems similar to oil and gas firms. Finally, while oil industry dynamics affected firm entry in the 1980s and renewed interest in the solar market in the 1990s, currently it seems that solar industry dynamics in terms of increased competition from new entrants affect further expansion plans and/or exit strategies. However, how these solar industry dynamics unfold and which role new entrants play in the emergence of the solar PV industry would be another area for further research.

To conclude, then, the recent investments of Shell and BP in unconventional oil and gas reserves such as tar sands point at a 'recarbonization' trend in the industry, which was stimulated by the record-high oil prices just prior to the global financial crisis. The oil firms seemingly stopped 
worrying about their public profile on climate change (Levy, 2009). What might have caused this change is the fact that in dealing with climate change, investments in renewables are no longer the main option for oil firms. Other mitigation measures including energy efficiency, emissions trading, biofuels and CCS have become more widespread (Pinkse and Kolk, 2009), which enable oil firms to stay closer to their oil and gas activities. Regrettably, policy makers might have incentivized this behaviour, because they have focused on the implementation of climate policy instruments to achieve near-term carbon targets (Sandén and Azar, 2005). Whereas emissions trading, due to relatively low allowance prices, has not yet provided an incentive strong enough to induce radical mitigation measures, it is particularly governments subsidizing CCS, which might have stimulated oil firms not to switch away from fossil fuels. Findings of this study therefore corroborate the call made earlier that policymakers need to put in place technology-specific instruments to stimulate market entry of more disruptive renewable energy technologies (Sandén and Azar, 2005).

\section{References}

Ahuja, G., \& Lampert, C. 2001. Entrepreneurship in the large corporation: a longitudinal study of how established firms create breakthrough inventions. Strategic Management Journal, 22: $521-543$.

Backer, L., \& Clark, T. S. 2008. Eco-Effective Greening Decisions and Rationalizations: The Case of Shell Renewables. Organization \& Environment, 21(3): 227-244.

Baumol, W. 2002. Entrepreneurship, innovation, and growth: the David-Goliath symbiosis. Journal of Entrepreneurial Finance and Business Ventures, 1: 1-18.

Boulton, L. 1997. Solar expansion planned by Shell. Financial Times, 7 October.

Bower, J., \& Christensen, C. 1995. Disruptive technologies: catching the wave. Harvard Business Review, 1: 43-53.

BP. 2008. Sustainability Review: 100 Years of Operating at the Frontiers. London: BP Publications. Buchan, D., \& Mallet, V., 2001. The captain of a very French multinational. Financial Times, 5 June. Chesbrough, H. 2003. The era of open innovation. MIT Sloan Management Review, 1: $35-41$.

Davis, J. 2006. 'Why don't oil companies commit to "renewables"?' A corporate constraints perspective. In J. Davis (Ed.), The Changing World of Oil: An Analysis of Corporate Change and Adaptation: 169-189. Aldershot: Ashgate Publishing.

Eikeland, P. O., Hasselknippe, H., \& Sæverud, I. A. 2004. Energy sector integration in Europe - The role of leading upstream oil and gas companies. FNI report 20/2004. Lysaker, Norway: The Fridtjof Nansen Institute.

Goetzberger, A., Luther, J., \& Willeke, G. 2002. Solar cells: past, present, future. Solar Energy and Solar Cells, 74: 1-11. 
Grant, R. M. 2003. Strategic planning in a turbulent environment: Evidence from the oil majors.

Strategic Management Journal, 24(6): 491-517.

Grant, R. M. 2005. Oil company strategies from 1970 to the present. In Eni (Ed.), Encyclopaedia of Hydrocarbons, Vol. IV: 301-321. Rome: The Instituto Della Enciclopedia Italiana Treccani.

Grant, R. M., \& Cibin, R. 1996. Strategy, structure and market turbulence: The international oil majors, 1970-1991. Scandinavian Journal of Management, 12(2): 165-188.

Gross, R., Leach, M., \& Bauen, A. 2003. Progress in renewable energy. Environmental international, 29: $105-122$.

Holdren, J. P. 2006. The energy innovation imperative: Addressing oil dependence, climate change, and other 21 st century energy challenges. Innovations: Technology, Governance, Globalization, 1: 3-23.

Jacobsson, S., \& Johnson, A. 2000. The diffusion of renewable energy technology: an analytical framework and key issues for research. Energy Policy, 28: 625-640.

Jacobsson, S., \& Bergek, A. 2004. Transforming the energy sector: the evolution of technological systems in renewable energy technology. Industrial and Corporate Change, 12: 815-849.

Jäger-Waldau, A. 2002. PV Status Report 2002. Ispra (VA), Italia: European Commission, DG Joint Research Centre, Institute for Energy, Renewable Energy Unit.

Jäger-Waldau, A. 2003. PV Status Report 2003. Ispra (VA), Italia: European Commission, DG Joint Research Centre, Institute for Energy, Renewable Energy Unit.

Jäger-Waldau, A. 2004. PV Status Report 2004. Ispra (VA), Italia: European Commission, DG Joint Research Centre, Institute for Energy, Renewable Energy Unit.

Jäger-Waldau, A. 2006. PV Status Report 2006. Ispra (VA), Italia: European Commission, DG Joint Research Centre, Institute for Energy, Renewable Energy Unit.

Jäger-Waldau, A. 2009. PV Status Report 2009. Ispra (VA), Italia: European Commission, DG Joint Research Centre, Institute for Energy, Renewable Energy Unit.

Kemp, R., Schot, J., \& Hoogma, R. 1998. Regime shifts to sustainability through processes of niche formation: The approach of strategic niche management. Technology Analysis \& Strategic Management, 10: 175-195.

Klepper, S. 1997. Industry life cycles. Industrial and Corporate Change, 6: 145-182.

Kolk, A., \& Levy, D. L. 2001. Winds of change: Corporate strategy, climate change and oil multinationals. European Management Journal, 19(5): 501-509.

Kolk, A., \& Levy, D. 2004. Multinationals and global climate change: issue for the automotive and oil industries. In S. M. Lundan (Ed.), Multinationals, Environment and Global Competition, Vol. 9: 171-193. Amsterdam: Elsevier. 
Kolk, A., \& Pinkse, J. 2008. A perspective on multinational enterprises and climate change: Learning from 'an inconvenient truth'? Journal of International Business Studies, 39: 1359-1378.

Levy, D. L. 2009. Back to petroleum? Climate Inc., 13 August.

Levy, D. L., \& Kolk, A. 2002. Strategic responses to global climate change: conflicting pressures on multinationals in the oil industry. Business \& Politics, 4(3): 275-300.

Milgrom, P., \& Roberts, J. 1990. The Economics of Modern Manufacturing: Technology, Strategy, and Organization. The American Economic Review, 80(3): 511-528.

Pinkse, J., \& Kolk, A. 2009. International Business and Global Climate Change. London: Routledge.

Pinkse, J., \& Kolk, A. 2010. Challenges and trade-offs in corporate innovation for climate change. Business Strategy and the Environment, in press.

Raven, R. Niche accumulation and hybridization strategies in transition processes towards a sustainable energy system: an assessment of differences and pitfalls. Energy Policy, 35: 23902400.

Reiche, D., \& Bechberger, M. 2004. Policy differences in the promotion of renewable energies in the EU member states. Energy Policy, 32(7): 843-849.

REN21. 2008. Renewables 2007 Global Status Report. Paris: REN21 Secretariat and Washington, DC: Worldwatch Institute.

REN21. 2009. Renewables Global Status Report: 2009 Update. Paris: REN21 Secretariat.

Rothwell, R. 1994. Towards the Fifth-generation innovation process. International Marketing Review, 11(1): 7-31.

Sæverud, I. A., \& Skjærseth, J. B. 2007. Oil companies and climate change: Inconsistencies between strategy formulation and implementation? Global Environmental Politics, 7(3): 42-62.

Sandén, B. A., \& Azar, C. 2005. Near-term technology policies for long-term climate targets economy wide versus technology specific approaches. Energy Policy, 33: 1557-1576.

Shell. 2008. Sustainability Report - Responsible Energy. The Hague: Shell publications.

Shum, K. L., \& Watanabe, C. 2007. Photovoltaic deployment strategy in Japan and the USA -an institutional appraisal. Energy Policy, 35: 1186-1195.

Total. 2007. Environment and Society - Our Corporate Responsibilities. Paris: Total publications.

Tsur, Y., \& Zemel. A. 2000. Long-term perspective on the development of solar energy. Solar Energy, 68: 379-392.

Unruh, G. C. 2000. Understanding carbon lock-in. Energy Policy, 28: 817-830.

Utterback, J., \& Abernathy, W. 1975. A dynamic model of process and product innovation. Omega, 3 : 639-656.

Van de Wateringen, S. L. 2005. The greening of black gold - Towards international environmental alignment in the petroleum industry. Veenendaal: Universal Press. 
World Energy Assessment. 2000. Energy and the Challenge of Sustainability. New York: United Nations Publications.

Yin, R. 1994. Case Study Research - Design and Methods. Thousand Oaks: Sage Publications. 